\title{
The Students' Self-Confidence and Their Mathematical Communication Skills in Solving Problems
}

\author{
Retta Aulia ${ }^{1}$, Rohati $^{1, \text { a) }}$, Marlina ${ }^{1}$ \\ ${ }^{1}$ Universitas Jambi \\ Jambi-Muara Bulian Street Km. 15, Mendalo Darat, Jaluko, Jambi, Indonesia, 36122 \\ a) rohati.fkip@unja.ac.id
}

\begin{abstract}
This research aims to analyze students' mathematical communication skills in solving mathematical problems based on their self-confidence. This research was a qualitative research method with a descriptive approach. This research was conducted at one of the junior high schools in Muaro Jambi, Jambi, Indonesia. The research subjects were six students consisting of two students with high self-confidence category, two students with medium category, and two students with low category who were selected using a purposive sampling technique. This research used student self-confidence questionnaires, problem-solving tests, and interviews to confirm the level of students' mathematical communication skills. The data were analyzed by descriptive technique. The results showed that the subjects with high self-confidence had met all indicators of mathematical communication skills. In contrast, the subjects with medium self-confidence had met three of four indicators of mathematical communication skills, and the subjects with low self-confidence only fulfill one of four indicators of mathematical communication skills.
\end{abstract}

Keywords: Mathematical Communication, Problem-Solving, Self-Confidence

\begin{abstract}
Abstrak. Penelitian ini bertujuan untuk menganalisis kemampuan komunikasi matematis siswa dalam menyelesaikan masalah matematika berdasarkan kepercayaan diri siswa. Penelitian ini menggunakan metode penelitian kualitatif dengan pendekatan deskriptif. Penelitian ini dilakukan di salah satu SMP di Muaro Jambi, Jambi, Indonesia. Subjek penelitian ini sebanyak enam siswa yang terdiri dari dua siswa dengan kategori percaya diri tinggi, dua siswa dengan kategori sedang, dan dua siswa dengan kategori rendah yang dipilih dengan teknik purposive sampling. Penelitian ini menggunakan angket kepercayaan diri siswa, tes pemecahan masalah, dan wawancara untuk mengkonfirmasi tingkat kemampuan komunikasi matematis siswa. Data dianalisis dengan teknik deskriptif. Hasil penelitian menunjukkan bahwa subjek dengan kepercayaan diri tinggi memenuhi semua indikator keterampilan komunikasi matematis, sedangkan subjek dengan kepercayaan diri sedang memenuhi tiga dari empat indikator keterampilan komunikasi matematis, dan subjek dengan kepercayaan diri rendah hanya memenuhi satu dari empat indikator keterampilan komunikasi matematis.
\end{abstract}

Kata kunci: Kepercayaan Diri, Komunikasi Matematis, Pemecahan Masalah 


\section{INTRODUCTION}

Mathematics is one of the subjects taught in schools that will help students grow their critical thinking and argumentation skills (Firdaus, Kailani, Bakar, \& Bakry, 2015; Gravemeijer, Stephan, Julie, Lin, \& Ohtani, 2017; Sanders, 2016), assist them in solving daily problems, and aid in the advancement of science and technology (Eyyam \& Yaratan, 2014; Park, 2006). Mathematics' requirements and implementations are not only for daily life but also for the world of work and the advancement of science. As a result, mathematics as a fundamental science must be thoroughly learned by students.

Mathematical communication is a necessary mathematical skill in the secondary school mathematics curriculum (Hendriana, Rohaeti, \& Sumarmo, 2017). Mathematics learning goals include the ability to convey ideas using symbols, charts, graphs, or mathematical terms to explain a situation or problem, as well as an attitude of appreciation for the utility of mathematics in life, a sense of curiosity, focus, and interest in mathematics, as well as a resilient and confident attitude toward problem-solving. Additionally, (Lomibao, Luna, \& Namoco, 2016; Paridjo \& Waluya, 2017; Surya \& Syahputra, 2017) argue that mathematical communication is critical to learning mathematics because it enables students to express, illustrate, describe, and listen, all of which contribute to a deeper understanding of mathematics.

Mathematics education allows users to communicate mathematically and practice regularly. This condition can be seen in the learning exercises in which the instructor requires students to complete or work on the material being taught and instructs them to write their responses on the whiteboard. This condition will work if students have a healthy sense of self-esteem. Students who have self-confidence would have an easier time interacting with teachers and other students while studying mathematics. Thus, self-confidence can motivate students to learn (Inkeeree, Fauzee, \& Othman, 2017; Justyna, 2017; Koca, 2016; Marks \& Fraley, 2007).

Finally, it is hoped that mathematics education will become more optimal. According to (Hendriana et al., 2017), students' self-confidence is essential for mathematics learning. Students who develop self-confidence would be more inspired and eager to learn mathematics. This condition implies that students who perform well in mathematics often have a high self-confidence index. As a result, each student must possess and grow self-confidence. According to (Abdel-Khaled, 2016; Hendriana et al., 2017), self-confidence is a sense of assurance in one's ability to unite and mobilize motivation and all necessary resources and put them to bear on the tasks at hand.

Additionally, student confidence in mathematics learning is a significant predictor of student confidence in interactions with the teacher and other students (Parsons, Croft, \& Harrison, 2009). This condition demonstrates that learning involves engagement and engaging in challenging and enjoyable activities to foster self-confidence. Students who develop a strong sense of self-confidence 
would be more willing to propose novel mathematical concepts. Furthermore, self-confidence enables students to engage and express themselves in the classroom while learning in a lively setting (Rizqi, Suyitno, \& Sudarmin, 2016).

However, the evidence on the ground indicates that students' mathematical communication abilities continue to be inadequate. (Kadir \& Parman, 2013; Noviyana, Rochmad, \& Dewi, 2020; Paruntu, Sukestiyarno, Priyono, \& Prasetyo, 2018; Rizqi et al., 2016; Rustam, 2018) demonstrates that junior high school students have inadequate mathematical communication skills. According to the author's findings at the start of the study at one of Muaro Jambi's junior high schools, the majority of students' mathematical communication skills remained poor. This disorder manifests itself throughout the learning process; students have trouble verbally and in writing expressing their comprehension. Many students are unable to respond when the teacher asks them questions about the content they have studied. They always refuse to respond verbally to teachers' questions. When given assignments, students often choose to copy their peers' work.

This condition was reinforced following interviews with the school's mathematics teacher; he revealed that the students' mathematical communication skills remained poor, especially their oral mathematical communication skills. When the teacher asked a question, only a tiny percentage of students dared or could respond. Meanwhile, some seventh-grade students admitted in interviews that they were often silent and unable to answer when teachers asked oral questions. Additionally, they are fearful of making errors when the instructor asks them to solve a problem on the blackboard. Additionally, they struggled when the teacher asked non-routine questions and felt perplexed when they asked questions that differed from the example questions given.

Numerous factors may contribute to students' lack of mathematical communication skills. One of them is the use of traditional learning styles, which encourage students to be passive and consider only the information offered by the instructor (Li \& Schoenfeld, 2019; Michael, 2015; Raj Acharya, 2017). As a result, students are unable to improve their mathematical communication abilities. Additionally, students are not used to solving mathematical problems using comprehensive and cogent resolution procedures. Students sometimes solve problems inadvertently, without describing each move. Additionally, the mathematics instructor indicated that the students' lack of mathematical communication abilities results from their lack of faith in their abilities. When it comes to sharing their mathematical theories, most students are hesitant or fearful of making errors. As a result, students find it challenging to improve their mathematical communication skills by problem-solving.

With some of these issues, it is crucial to conduct an in-depth examination of students' mathematical abilities, especially their mathematical communication abilities. To prevent anxiety and doubt when learning mathematical communication skills, a student must have a confident and trusting attitude toward their abilities (Asih, Isnarto, \& Sukestiyarno, 2021; Darling-Hammond, 
Flook, Cook-Harvey, Barron, \& Osher, 2020; Paroqi, Malikussaleh, \& Marhami, 2020). Teachers play a critical role in promoting student trust in schools because they strongly influence the learning and learning process.

Trust is a constant work in progress. Self-confidence can be developed; however, it is most effective when developed under the instructor's supervision during learning activities. Students' selfconfidence can be improved at school by engaging them actively in all learning processes. This condition is consistent with the assertion (Rizqi et al., 2016) that students should convey their ideas confidently to explain them to solve the problems they articulate. Additionally, teachers must provide additional opportunities for students to generate ideas through the oral and written communication of their mathematical knowledge through algebraic descriptions, images, diagrams, or other mathematical models. Since mathematical communication skills are critical, educators must understand them and be familiar with the aspects or measures of mathematical communication skills. Mathematics instruction should be implemented as efficiently as possible to improve mathematical communication skills (Deswita, Kusumah, \& Dahlan, 2018). This study aims to uncover mathematical communication skills in students' self-confidence when solving mathematical problems.

\section{METHOD}

This research uses a qualitative research method that employs a descriptive approach. In the even semester of the 2018/2019 academic year, this study was performed in grade seven at one of Muaro Jambi's junior high schools. Purposive sampling was used to determine the sample size. Purposive sampling is a method for intentionally selecting and preparing research subjects to aid researchers in comprehending the issue under investigation (Creswell, 2014). A self-confidence questionnaire was used to identify and categorize students who possessed high, medium, or low self-confidence in this study.

The author selects the subject by administering a self-esteem questionnaire to seventh-grade students. As a result, six subjects were obtained: two with a high level of self-confidence, two with a moderate level of self-confidence, and two with a low level of self-confidence. Additionally, each subject was given a sheet of quadrilateral problem-solving questions. Following the administration of test questions, the researcher interviewed research subjects to elicit additional information about the students' mathematical communication abilities and their level of proficiency. Finally, the data's validity was established through source triangulation and technique triangulation.

The outcomes of written assessments of mathematical communication skills and interviews will be evaluated to determine the subject's problem-solving skills through recalling or building information. Then, to determine the level of achievement of the students' mathematical 
communication ability measures, the written test results are scored according to the scoring guidelines proposed by (Danaryanti \& Noviani, 2015). Following that, each predictor of mathematical communication skills can be evaluated. If the percentage falls within the minimum (34-66) percent category, the indicator is satisfied. According to (Wijayanto, Fajriah, \& Anita, 2018), the following standards of achievement exist:

Table 1. Degree of Proficiency in Mathematical Communication

\begin{tabular}{cc}
\hline Mathematical Communication Achievement & Category \\
\hline$\leq 33 \%$ & Low \\
\hline$>33 \%$ & Moderate \\
\hline$>66 \%$ & High \\
\hline
\end{tabular}

Meanwhile, qualitative data analysis was conducted in this study using technical analysis, which, according to (Miles, Huberman, \& Saldana, 2014), entails (1) data reduction, (2) data presentation, and (3) conclusion drawing.

\section{RESULTS AND DISCUSSION}

The study subjects were chosen by administering a self-confidence questionnaire to thirty seventhgrade students. The questionnaire includes statements about student self-confidence that have been calibrated against self-confidence measures. This trust questionnaire includes 39 statements with four possible responses: Strongly Accept (SA), Agree (A), Disagree (D), and Strongly Disagree (SD). Additionally, questionnaire items include favorable $(+)$ items, which indicate trust, and unfavorable (-) items, which indicate a lack of confidence. Eight students with high self-confidence, ten students with moderate self-confidence, and twelve students with low self-confidence completed the selfconfidence questionnaire. The following table summarizes the total percentage of responses to a questionnaire administered to seventh-grade students about their self-confidence:

Table 2. The confidence level of students as a percentage

\begin{tabular}{ccc}
\hline Category & Frequency & Percentage \\
\hline High & 8 & $26,67 \%$ \\
\hline Moderate & 10 & $33,33 \%$ \\
\hline Low & 12 & $40 \%$ \\
\hline Total & 30 & $100 \%$ \\
\hline
\end{tabular}

According to the table, most students in the class chosen for the study population have low self-confidence, accounting for $40 \%$ of total students; this is consistent with the researcher's expectations. Additionally, the researchers discussed the results of self-confidence questionnaires administered by mathematics teachers to students in the seventh grade to establish a correlation between the scores and the characteristics of students' self-confidence.

The researcher then chose six students as study subjects: two students with a high level of selfconfidence, two students with a medium level of self-confidence, and two students with a low level 
of self-confidence. The two students with the highest questionnaire scores in each group were chosen. Thus, based on the results of the self-confidence questionnaire and discussion with the mathematics instructor, the six subjects can be coded as follows:

Table 3. Subjects' Coding

\begin{tabular}{lcccc}
\hline No & $\begin{array}{c}\text { Student Name } \\
\text { Code }\end{array}$ & Score & Coding & Information \\
\hline 1. & F10 & 140 & HSC1 & High Self-Confidence 1 \\
\hline 2. & F1 & 127 & HSC2 & High Self-Confidence 2 \\
\hline 3. & F4 & 116 & MSC1 & Moderate Self-Confidence 1 \\
\hline 4. & M1 & 114 & MSC2 & Moderate Self-Confidence 2 \\
\hline 5. & M11 & 76 & LSC1 & Low Self-Confidence 1 \\
\hline 6. & M15 & 74 & LSC2 & Low Self-Confidence 2 \\
\hline
\end{tabular}

After recruiting six students as study subjects, the subjects are presented with two quadrilateral problem-solving exercises. Mathematicians and teachers of mathematics subjects have validated these problems. The following move was to interview six research subjects. Following the collection of written and oral test data, an examination of the students' mathematical communication skills was conducted, and the following results were obtained:

\begin{tabular}{|c|c|c|c|}
\hline No & The Subject & Indicators are Satisfied & Non-Conformance with Indicators \\
\hline 1. & HSC1 & $\begin{array}{l}\text { Grammar Abilities, Comprehension of } \\
\text { Discourse, Sociolinguistic Abilities, } \\
\text { and Strategic Abilities. }\end{array}$ & \\
\hline 2. & HSC2 & $\begin{array}{c}\text { Grammar Abilities, Comprehension of } \\
\text { Discourse, Sociolinguistic Abilities, } \\
\text { and Strategic Abilities. }\end{array}$ & \\
\hline 3. & MSC1 & $\begin{array}{l}\text { Grammar Abilities, Comprehension of } \\
\text { Discourse, and Sociolinguistic Abilities }\end{array}$ & Strategic Abilities \\
\hline 4. & MSC2 & $\begin{array}{l}\text { Grammar Abilities, Comprehension of } \\
\text { Discourse, and Sociolinguistic Abilities }\end{array}$ & Strategic Abilities \\
\hline 5. & LSC1 & Sociolinguistic Abilities & $\begin{array}{l}\text { Grammar Abilities, Comprehension } \\
\text { of Discourse, and Strategic Abilities. }\end{array}$ \\
\hline 6. & LSC2 & Sociolinguistic Abilities & $\begin{array}{l}\text { Grammar Abilities, Comprehension } \\
\text { of Discourse, and Strategic Abilities. }\end{array}$ \\
\hline
\end{tabular}

The study results indicate that students with high self-confidence (HSC) and moderate selfconfidence (MSC) met the indicators of mathematical communication skills when solving quadrilateral material problems. However, students classified as having low self-confidence (LSC) did not follow the indicators of mathematical communication skills.

According to the problem-solving question sheet (Figure 1) and the interview on mathematical communication skills, the HSC1 subject (High Self-Confidence 1) clearly understands the problem. HSC1 has established an effective problem-solving strategy. HSC1 is capable of solving problems simply and almost entirely. HSC1 can provide a logically sound supporting statement, but with a few minor errors. HSC1 is proficient in using mathematical expressions, symbols, notations, and operations. The HSC1 is capable of producing images that are nearly precise and complete. HSC1 is 
capable of producing succinct and accurate conclusions. As a result, the HSC1 subject possesses level 3 mathematical communication skills.

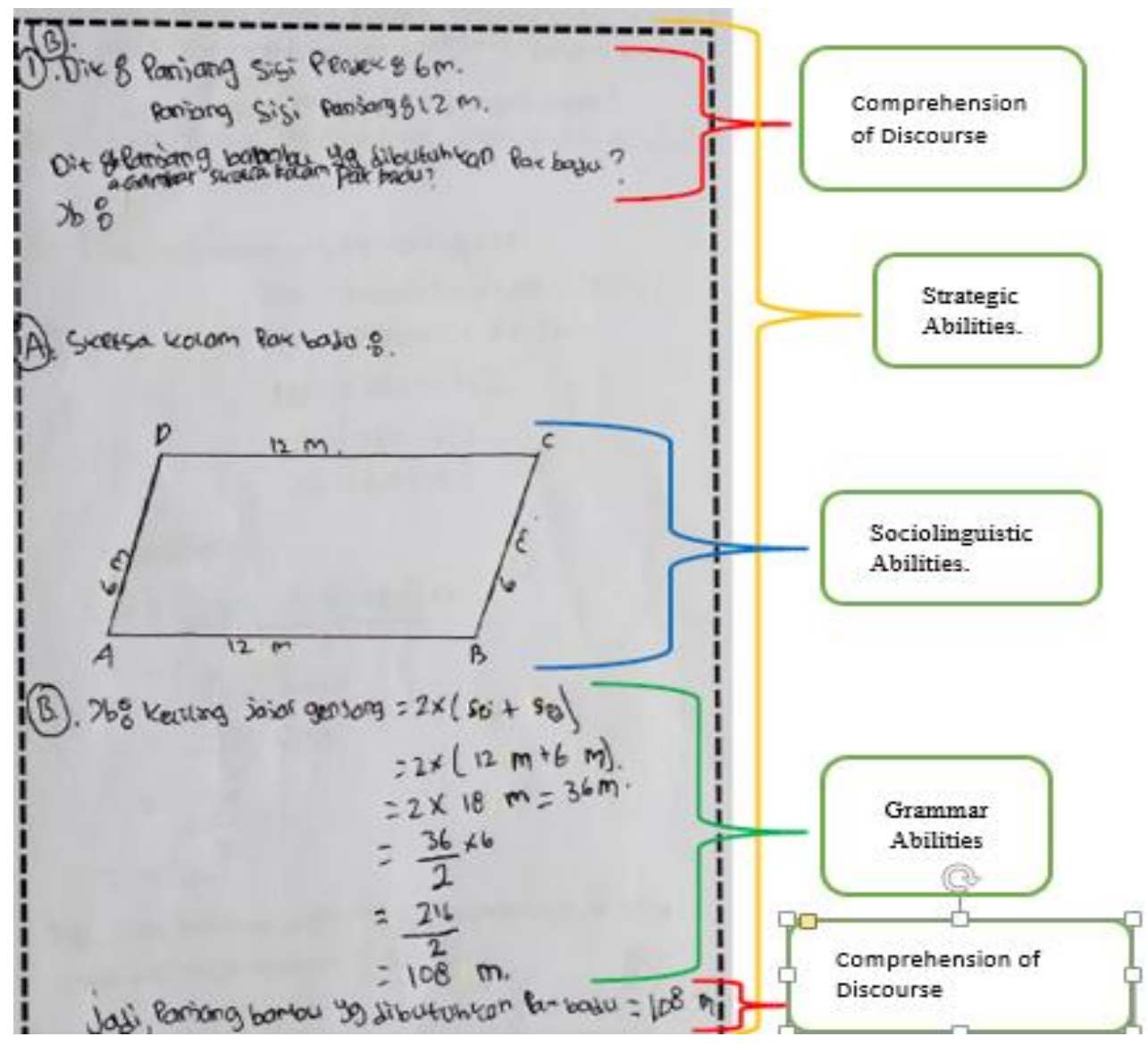

Figure 1. HSC1 student answer

Similarly, the subject of HSC2 (High Confidence 2) has a firm grasp of the issue. HSC2 has been able to provide nearly exhaustive answers accompanied by logical descriptions. HSC2 is capable of solving problems simply and almost entirely. HSC2 can provide a logically sound supporting statement, but with a few minor errors. HSC2 is capable of adequately using mathematical expressions, symbols, notations, and operations. HSC2 is capable of generating an image that is nearly precise and complete (Figure 2). HSC2 is capable of producing accurate and lucid conclusions. As a result, the HSC2 subject possesses level 3 mathematical communication skills. This condition, according to (Hanifah, Waluya, Rochmad, \& Wardono, 2020; Nurhayati, Rosmaiyadi, \& Buyung, 2017; Rabbani \& Herman, 2017; Rizqi et al., 2016), demonstrates that students with high selfconfidence can express mathematical ideas coherently and clearly through oral and written communication. Students can also thoroughly and accurately describe mathematical ideas visually, such as graphs, diagrams, geometric, and others. 


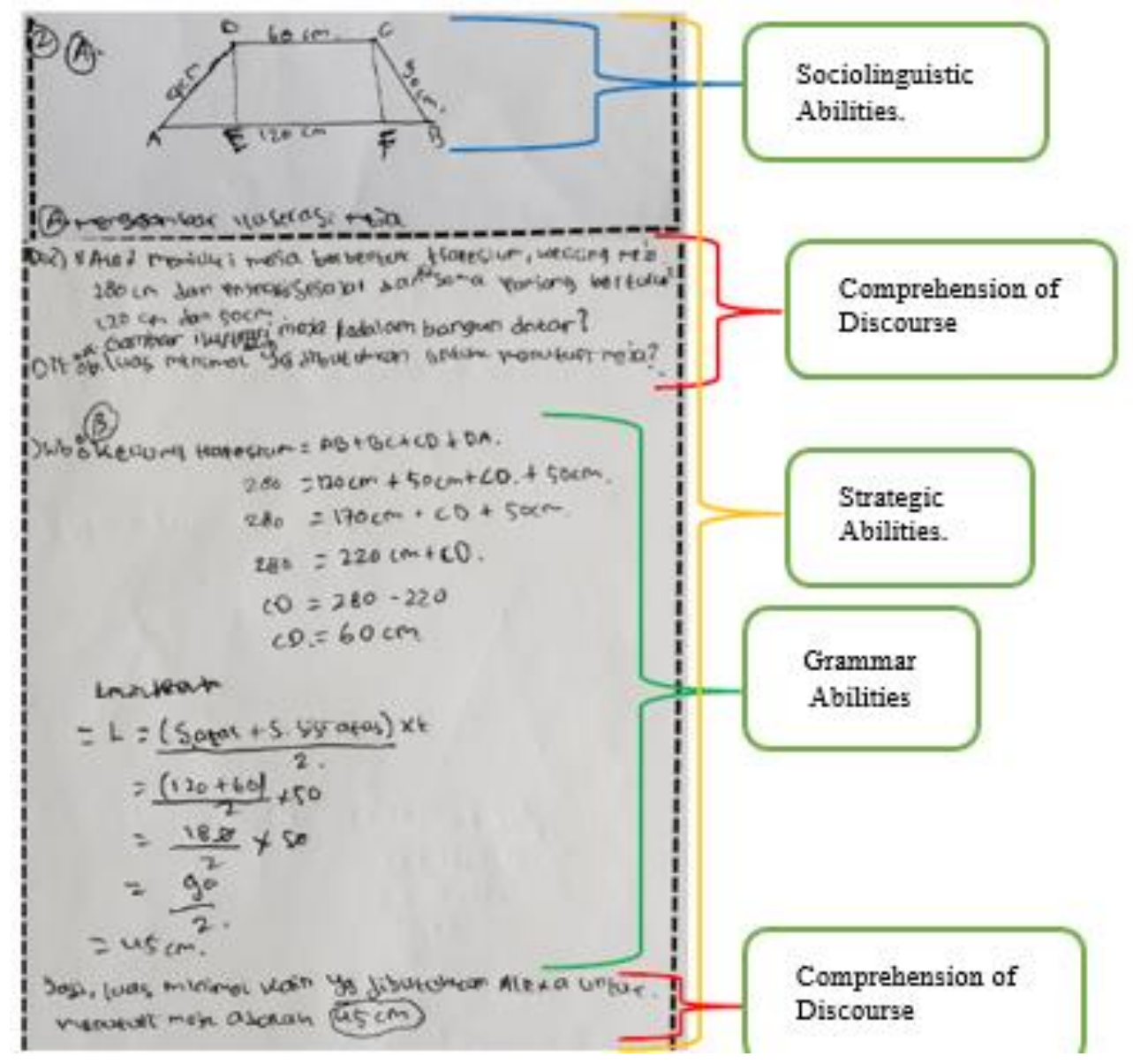

Figure 2. HSC2 student answers

The subject of MSC1 (Moderate Confidence 1) is already very familiar with the issue. MSC1 was able to formulate a problem-solving strategy, despite the presence of errors. MSC1 is very capable of problem-solving. MSC1 explains, but it remains somewhat vague or undefined. MSC1 can generate an image, but it is not accurate or precise (Figure 3). MSC1 is incapable of drawing accurate and conclusive conclusions. As a result, the MSC1 subject possesses level 2 mathematical communication skills (moderate). 


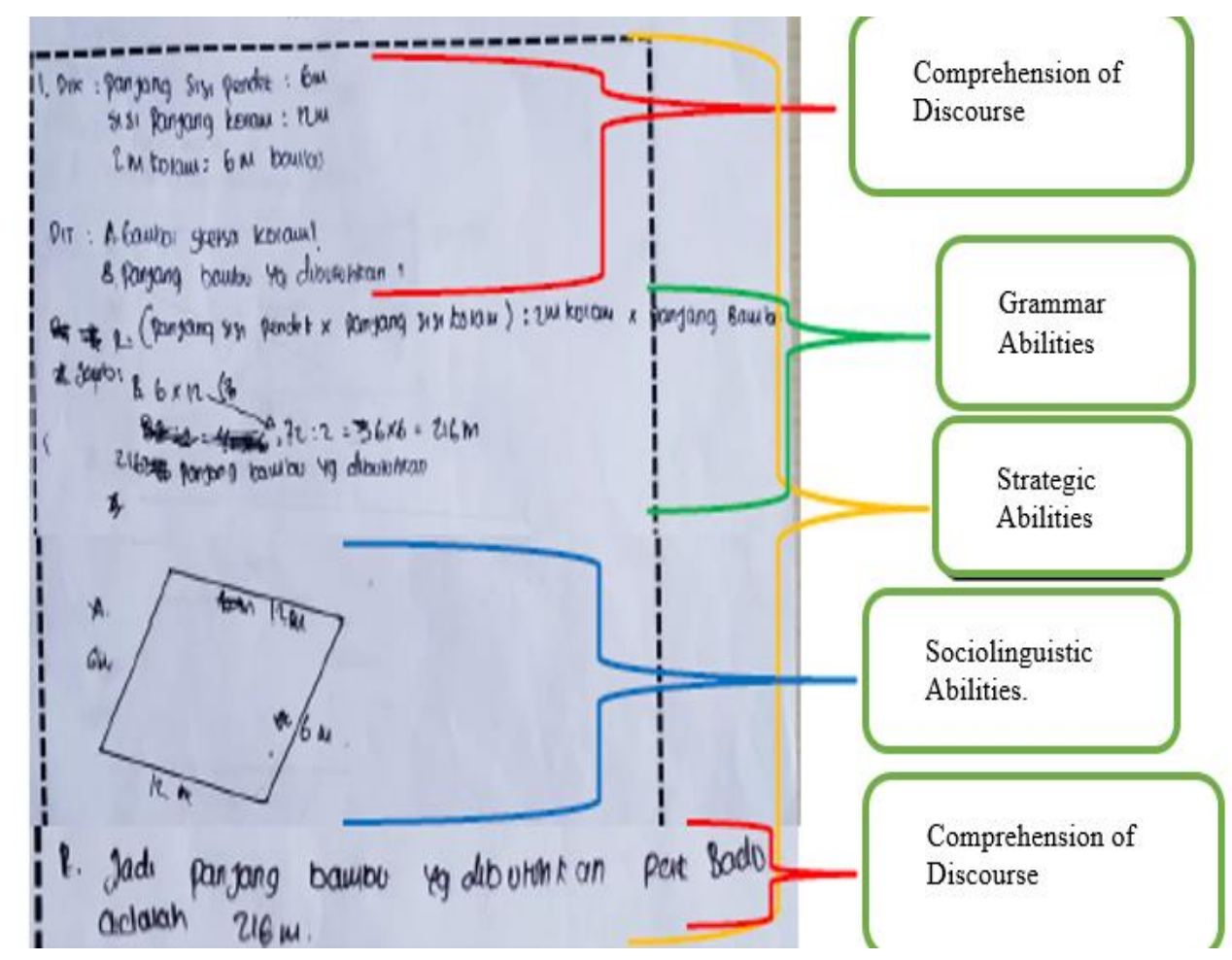

Figure 3. MSC1 student answers

Similarly, the subject of MSC2 (Moderate Confidence 2) has a good grasp of the problem. MSC2 has been able to develop a problem-solving strategy, but with some mistakes. MSC2 is very capable of problem-solving. While MSC2 provides a logical interpretation, it remains vague or uncertain. MSC2 is capable of rendering the image, but it is not precise. MSC2 is incapable of drawing accurate and conclusive conclusions (Figure 4). As a result, the MSC2 subject needs level 2 mathematical communication skills (moderate). According to (Barizah \& Jupri, 2019; Noviyana et al., 2020; Rizqi et al., 2016), students in the self-confidence group can express mathematical ideas. The use of mathematical terms and notations is very effective in visualizing mathematical concepts. 


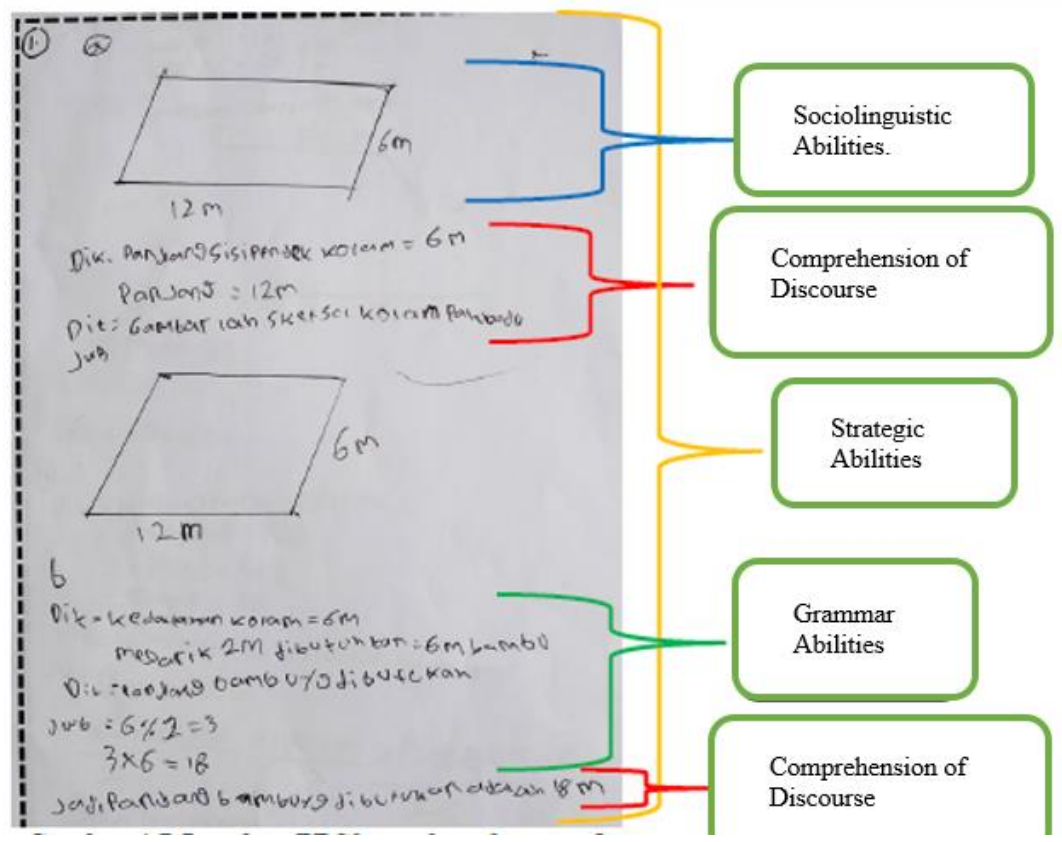

Figure 4. MSC2 student answers

LSC1 (Low Self Confidence 1)'s subject has a poor understanding of the issue. LSC1 does not include a complete response but does provide some of the required components (figure 5).

LSC1 is less capable of justifying each logically correct response. LSC1 contains an image but is unable to interpret it. LSC1 does not have conclusive proof. As a result, the LSC1 subject possesses level 1 mathematical communication skills (less).

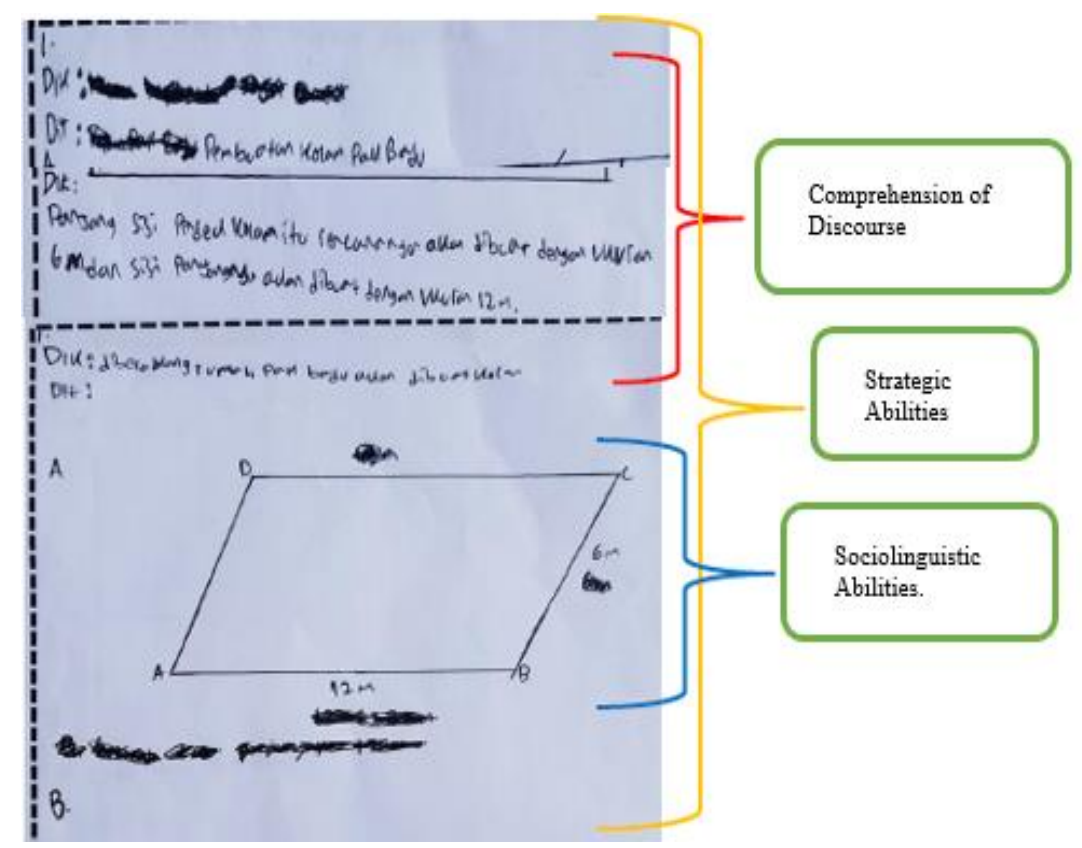

Figure 5. LSC1 student answers

Similarly, the subject of LSC2 (Low Self-Confidence 2) is incapable of comprehending the issue. LSC2 does not include a complete answer but does contain some correct elements. LSC2 is 
less capable of rationalizing each logically correct response (Figure 6). LSC2 contains an image but is unable to interpret it correctly. LSC2 does not have conclusive proof. As a result, the LSC2 subject possesses level 1 mathematical communication skills (less). This result is based on (Barizah \& Jupri, 2019; Wardono, Rochmad, Uswatun, \& Mariani, 2020; Wijayanto et al., 2018), which indicates that students fall into the low self-confidence category are less certain, embarrassed, and uncertain about their behavior.

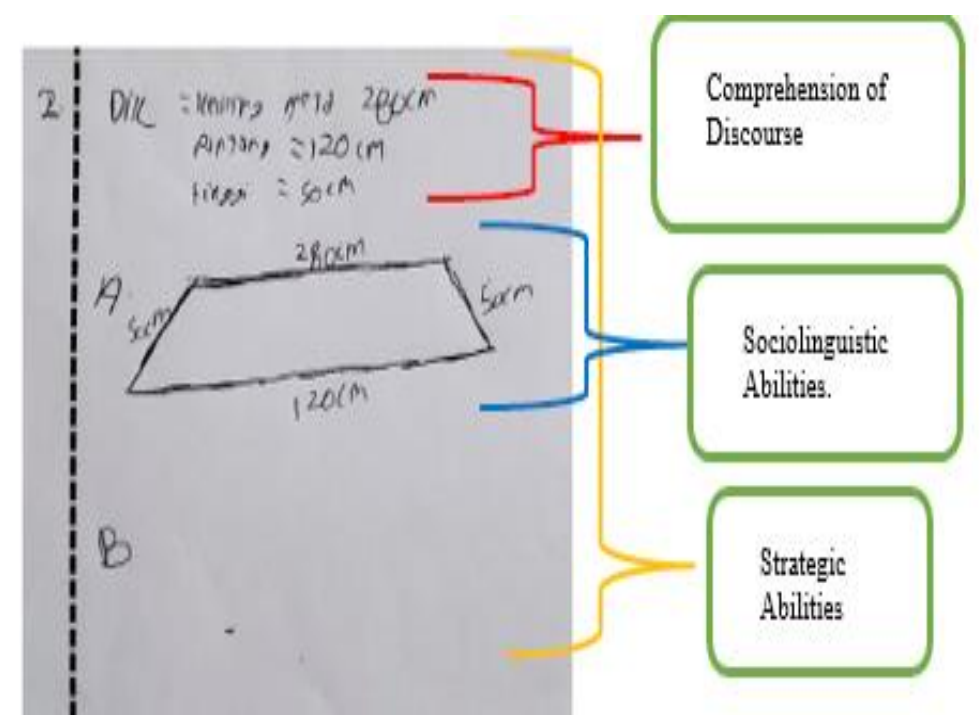

Figure 6. LSC2 student answers

\section{CONCLUSION}

According to the study findings, the subject possesses a high level of self-confidence (HSC) and a proclivity for mathematical communication. HSC met all four indicators of mathematical communication capacity. The HSC grammar skills will correctly use symbols or notations and perform operations. The capacity to comprehend HSC discourse allowed the complete and accurate presentation of known and challenging elements and the formation of consistent conclusions upon completion. Furthermore, subjects with moderate self-confidence (MSC) have moderate mathematical communication skills. MSC has reached three of the four indicators of mathematical communication skills but not the other three indicators of strategic capabilities. The MSC grammar skills are capable of correctly using symbols or notations and performing operations, but there are still some minor errors. The capacity to comprehend MSC discourse has revealed and challenged nearly correct and total elements and has been able to bring conclusions to a satisfactory conclusion.

According to the study's findings, subjects with low self-confidence (LSC) have poor mathematical communication skills. LSC satisfies only one of the four measures of mathematical communication capacity, namely the indicator of sociolinguistic ability. The LSC grammar skills are unable to operate on symbols or notations. Understanding the LSC debate has revealed and challenged features but is unrelated to the problem situation and thus incapable of concluding. The 
LSC's sociolinguistic capacity enables it to present contextual problems accurately and almost entirely through photographs. LSC, in its strategic potential, is incapable of solving problems coherently; it is incapable of formulating solutions; it is incapable of initiating settlement steps, and it is incapable of producing final results. Mathematics teachers can continue to develop students' mathematical communication skills by pattern solving (Barizah \& Jupri, 2019; Hanifah et al., 2020; Nurhayati et al., 2017; Rabbani \& Herman, 2017; Simanjuntak, Rajagukguk, \& Rangkuti, 2020; Wardono et al., 2020; Yuniara, 2016). The findings of this study can be used to educate and illuminate future studies on the degree of students' mathematical communication skills in terms of their self-confidence when solving mathematical problems.

\section{REFERENCES}

Abdel-Khaled, A. M. (2016). Introduction to the Psychology of self-esteem. In F. Holloway (Ed.), Self-Esteem (pp. 1-5). New York: Nova Science Publishers, Inc.

Asih, K. S., Isnarto, \& Sukestiyarno. (2021). Mathematical Communication Skills Reviewed From Mathematical Resilience in Independent Learning and Discovery Learning Assisted by E-Learning. Unnes Journal of Mathematics Education Research, 10(79), 112-120.

Barizah, N., \& Jupri, A. (2019). The Analysis of Mathematical Communication Ability for Students in Quadrilateral at 8th grade on Islamic Junior High School. 1st International Seminar STEMEIF (Science, and Mathematics Learning International Forum), 296-302. Purwokerto.

Creswell, J. W. (2014). Research Design : Qualitative, Quantitative, and Mixed Methods Approaches (Fourth; V. Knight, ed.). California: SAGE Publications Ltd.

Danaryanti, A., \& Noviani, H. (2015). Pengaruh Gaya Belajar Matematika Siswa Kelas VII terhadap Kemampuan Komunikasi Matematis di SMP. EDU-MAT Jurnal Pendidikan Matematika, 3(2), 204-212. Retrieved from www.journal.uta45jakarta.ac.id

Darling-Hammond, L., Flook, L., Cook-Harvey, C., Barron, B., \& Osher, D. (2020). Implications for educational practice of the science of learning and development. Applied Developmental Science, 24(2), 97-140. https://doi.org/10.1080/10888691.2018.1537791

Deswita, R., Kusumah, Y. S., \& Dahlan, J. A. (2018). Peningkatan Kemampuan Komunikasi Matematis Siswa Melalui Model Pembelajaran CORE dengan Pendekatan Scientific. Edumatika : Jurnal Riset Pendidikan Matematika, 1(1), 35. https://doi.org/10.32939/ejrpm.v1i1.220

Eyyam, R., \& Yaratan, H. S. (2014). Impact of Use of Technology in Mathematics Lessons on Student Achievement and Attitudes. Social Behavior and Personality: An International Journal, 42(1), 31S-42S. https://doi.org/10.2224/sbp.2014.42.0.s31

Firdaus, F., Kailani, I., Bakar, M. N. Bin, \& Bakry, B. (2015). Developing Critical Thinking Skills of Students in Mathematics Learning. Journal of Education and Learning (EduLearn), 9(3), 226-236. https://doi.org/10.11591/edulearn.v9i3.1830

Gravemeijer, K., Stephan, M., Julie, C., Lin, F. L., \& Ohtani, M. (2017). What Mathematics Education May Prepare Students for the Society of the Future? International Journal of Science and Mathematics Education, 15, 105-123. https://doi.org/10.1007/s10763-017-9814-6

Hanifah, Waluya, S. B., Rochmad, \& Wardono. (2020). Mathematical Representation Ability and Self Efficacy. Journal of Physics: Conference Series, 1613(1). https://doi.org/10.1088/17426596/1613/1/012062

Hendriana, H., Rohaeti, E., \& Sumarmo, U. (2017). Hard Skills dan Soft Skills Matematik Siswa. Bandung: PT Refika Adimata.

Inkeeree, H. K.-, Fauzee, M. S. O.-, \& Othman, M. K. H. (2017). The Effect of Students Confidence Level toward Mathematics Performance among Southern Thailand Primary School Children. International 
Journal of Academic Research in Progressive Education and Development, 6(2), $20-34$. https://doi.org/10.6007/ijarped/v6-i2/2934

Justyna, W. (2017). Teacher and Teaching Effects on Students' Attitudes and Behaviors. Educ Eval Policy Anal., 176(5), 139-148. https://doi.org/10.1016/j.physbeh.2017.03.040

Kadir, J., \& Parman, M. S. (2013). Mathematical Communication Skills of Junior Secondary School Students in. Jurnal Teknologi, 2(63), 77-83.

Koca, F. (2016). Motivation to Learn and Teacher-Student Relationship. Journal of International Education and Leadership, 6(2).

Li, Y., \& Schoenfeld, A. H. (2019). Problematizing teaching and learning mathematics as "given" in STEM education. International Journal of STEM Education, 6(1). https://doi.org/10.1186/s40594-019-0197-9

Lomibao, L. S., Luna, C. A., \& Namoco, R. A. (2016). The Influence of Mathematical Communication on Students' Mathematics Performance and Anxiety. American Journal of Educational Research, 4(5), 378-382. https://doi.org/10.12691/education-4-5-3

Marks, M. J., \& Fraley, R. C. (2007). The impact of social interaction on the sexual double standard. Social Influence, 2(1), 29-54. https://doi.org/10.1080/15534510601154413

Michael, I. (2015). Factors Leading To Poor Performance in Mathematics. Open University of Tanzania, 88.

Miles, M. B., Huberman, A. M., \& Saldana, J. (2014). Qualitative Data Analysis A Methods Sourcebook (third). California: SAGE Publications Ltd. https://doi.org/10.7748/ns.30.25.33.s40

Noviyana, I. N., Rochmad, \& Dewi, N. R. (2020). Unnes Journal of Mathematics Education Research Student Mathematical Communication Ability Viewed from Self-Confidence in the ARIAS Model Nuanced Ethnomathematics. Unnes Journal of Mathematics Education Research, 9(1), 2020-2106. Retrieved from http://journal.unnes.ac.id/sju/index.php/ujmer

Nurhayati, N., Rosmaiyadi, R., \& Buyung, B. (2017). Efforts To Improve Student'S Self Confidence Using Collaborative Learning Model. JPMI (Jurnal Pendidikan Matematika Indonesia), 2(2), 57. https://doi.org/10.26737/jpmi.v2i2.223

Paridjo, P., \& Waluya, S. B. (2017). Analysis Mathematical Communication Skills Students In The Matter Algebra-Based NCTM. IOSR Journal of Mathematics, 13(01), 60-66. https://doi.org/10.9790/57281301056066

Park, H. S. (2006). Development of a mathematics, science, and technology education integrated program for a Maglev. Eurasia Journal of Mathematics, Science and Technology Education, 2(3), 88-100. https://doi.org/10.12973/ejmste/75467

Paroqi, L. L., Malikussaleh, \& Marhami. (2020). The Implementation of Realistic Mathematics Education Approach to Improve Students ' Mathematical Communication Ability in Statistics Course. International Journal for Educational and Vocational Studies, 2(10), 879-889. https://doi.org/https://doi.org/10.29103/ijevs.v2i10.3311

Parsons, S., Croft, T., \& Harrison, M. (2009). Does students' confidence in their ability in mathematics matter'. Teaching Mathematics and Its Applications, 28(2), 53-68. https://doi.org/10.1093/teamat/hrp010

Paruntu, P. E., Sukestiyarno, Y. L., Priyono, A., \& Prasetyo, B. (2018). Analysis of Mathematical Communication Ability and Curiosity Through Project-Based Learning Models With Scaffolding. Unnes Journal of Mathematics Education Research, 7(1), 26-34.

Rabbani, S., \& Herman, T. (2017). Increasing Formulate and Test Conjecture Math Competence and Self Confidence in Using the Discovery Learning Teaching Math. PrimaryEdu - Journal of Primary Education, 1(1), 119. https://doi.org/10.22460/pej.v1i1.488

Raj Acharya, B. (2017). Factors Affecting Difficulties in Learning Mathematics by Mathematics Learners. International Journal of Elementary Education, 6(2), 8. https://doi.org/10.11648/j.ijeedu.20170602.11

Rizqi, A. A., Suyitno, H., \& Sudarmin, S. (2016). Analisis Kemampuan Komunikasi Matematis Ditinjau Dari Kepercayaan Diri Siswa Melalui Blended Learning. Unnes Journal of Mathematics Education Research, 5(1), 17-23.

Rustam, A. (2018). Analysis of Mathematical Communication Skills of Junior High School of Coastal Kolaka. 
Journal of Mathematics Education, 2(2), 45-51.

Sanders, S. (2016). Critical and Creative Thinkers in Mathematics Classrooms. Journal of Student Engagement: Education Matters, 6(1), 19.

Simanjuntak, S. A., Rajagukguk, W., \& Rangkuti, Y. M. (2020). Improvement of Mathematical Communication Skills and Student Learning Motivation Through Realistic Mathematics Education Approaches. In B. Sinaga, R. Husein, \& J. Rajagukguk (Eds.), Proceedings of The 5th Annual International Seminar on Transformative Education and Educational Leadership (AISTEEL) (pp. 137140). Medan: Universitas Negeri Medan.

Surya, E., \& Syahputra, E. (2017). Analysis of Student Mathematical Problem Solving Skills At Budi Analysis Mathematical Communication Skills Student At the Grade. IJARIIE, 3(February), 2160-2164.

Wardono, Rochmad, Uswatun, K., \& Mariani, S. (2020). Comparison between generative learning and discovery learning in improving written mathematical communication ability. International Journal of Instruction, 13(3), 729-744. https://doi.org/10.29333/iji.2020.13349a

Wijayanto, A. D., Fajriah, S. N., \& Anita, I. W. (2018). Analisis Kemampuan Komunikasi Matematis Siswa Smp Pada Materi Segitiga Dan Segiempat. Jurnal Cendekia : Jurnal Pendidikan Matematika, 2(1), 97104. https://doi.org/10.31004/cendekia.v2i1.36

Yuniara, R. (2016). Students' Mathematical Communication Skills In Finding The Concept Of Direct And Inverse Proportions Through Discovery Learning. Proceedings of the 1st English Education International Conference (EEIC), (5), 358-361. 